\title{
Investigation of trefoil factor expression in saliva and oral mucosal tissues of patients with oral squamous cell carcinoma
}

Ponlatham Chaiyarit ${ }^{1}$; Akasith Utrawichian ${ }^{2}$; Chanvit Leelayuwat ${ }^{3}$; Patrawut Vatanasapt $^{4}$;

Nattharee Chanchareonsook ${ }^{5}$; Mie Hessellund Samson ${ }^{6}$; Andrew S. Giraud ${ }^{7}$

${ }^{1}$ Department of Oral Diagnosis, Faculty of Dentistry, Khon Kaen University, Khon Kaen 40002, Thailand

${ }^{2}$ Department of Oral and Maxillofacial Surgery, Faculty of Dentistry, Khon Kaen University, Khon Kaen 40002, Thailand

${ }^{3}$ Department of Clinical Immunology and Transfusion Medicine

The Centre for Research and Development of Medical Diagnostic Laboratories

Faculty of Associated Medical Sciences, Khon Kaen University

Khon Kaen 40002, Thailand

${ }^{4}$ Department of Otorhinolaryngology, Faculty of Medicine, Khon Kaen University, Khon Kaen 40002, Thailand

${ }^{5}$ Registrar, Department of Oral and Maxillofacial Surgery

National Dental Centre Singapore, 5 Second Hospital Avenue

Singapore 168938

${ }^{6}$ Department of Clinical Biochemistry, Aarhus University Hospital,

DK-8000 Aarhus C, Denmark

${ }^{7}$ Murdoch Childrens Research Institute, The Royal Children's Hospital

Flemington Road Parkville Victoria 3052, Australia

\section{Short running title:}

Trefoil factors in patients with oral squamous cell carcinoma

\section{Corresponding author}

Associate Professor Ponlatham Chaiyarit

Department of Oral Diagnosis

Faculty of Dentistry, Khon Kaen University

Khon Kaen 40002

Thailand

Tel: +6643202405 ext 11154

Fax: +6643202862

E-mail: cponla@kku.ac.th

$$
\text { pchaiyarit@yahoo.com }
$$




\begin{abstract}
Objectives: The aims of our study were to determine levels of trefoil factor (TFF) peptides in saliva and oral mucosal tissues from patients with oral squamous cell carcinoma (OSCC), and to evaluate whether individual members of TFFs (TFF1, TFF2, and TFF3) might act as biomarkers of disease.
\end{abstract}

Materials and Methods: Saliva samples were from 23 healthy subjects, and 23 OSCC patients. Tissue samples were collected from 32 normal oral mucosa (NOM) and 32 OSCC biopsy specimens. ELISA and immunohistochemical methods were used to evaluate the expression of TFF1, TFF2, and TFF3 in saliva and oral mucosal tissues, respectively. Results: Expression of TFF2 and TFF3 in oral mucosal tissues of OSCC patients was strongly down-regulated when compared to healthy subjects $(\mathrm{p}<0.001$ and $\mathrm{p}=0.002$, respectively). However, there were no differences in levels of salivary TFF concentrations between OSCC patients and healthy subjects.

Conclusions: The present study extends previous observations, demonstrating the reduction of TFF2 and TFF3 expression in oral mucosal tissues of OSCC patients.

Clinical Relevance: These findings suggest the clinical significance of TFF2 and TFF3 molecules as negative markers of tumor progression in OSCC. Quantification of TFF levels in saliva may not be optimal in terms of diagnostic or predictive value for OSCC derived from oral mucosa.

Keywords: ELISA; immunohistochemistry; oral cancer; saliva; trefoil factors 


\section{Introduction}

Trefoil factors (TFFs) belong to a family of short peptides with disulfide bonds that form a trefoil domain. Human TFFs consist of three members, TFF1, TFF2, and TFF3 [1-3]. TFF1 contains one trefoil domain and can be found as a monomer or a dimer with molecular weight of $6.5 \mathrm{kDa}$ and $14 \mathrm{kDa}$, respectively. TFF2 contains two trefoil domains with approximate molecular weight of $12 \mathrm{kDa}$. Molecular weight of TFF2 can be variable due to glycosylation. TFF3 contains one trefoil domain and has a molecular weight of $6.6 \mathrm{kDa}$ in a monomeric form or $13 \mathrm{kDa}$ in a dimeric form [4]. The genes encoding these TFF peptides are located on human chromosome 21q22.3 [5]. TFF peptides are secreted from mucinproducing epithelial cells of the gastrointestinal tract [6] and TFFs were detected in other tissues such as brain, tear ducts, salivary glands, parotid ducts and oral mucosa, respiratory tract, lymphoid tissue, liver and gall bladder, and uterus [7-16]. Secreted TFF peptides were detected in serum, saliva, milk, gastric juice, pancreatic fluid, and urine [17-23].

Previous studies demonstrated that TFF expression was upregulated by various factors including local protein regulators such as growth factors [24, 25], growth hormones [26, 27], and several cytokines such as IL-4 and Il-13 [28]. In contrast, TFF expression was downregulated by proinflammatory cytokines such as IL-1beta and IL-6 [29] and by microbial pathogens such as Helicobacter pylori $[30,31]$. It was suggested that the SHP2/Erk or JAK/STAT signaling pathways [32] might be involved in the upregulation of TFF expression, whereas $\mathrm{C} / \mathrm{EBP} \beta$ and $\mathrm{NF} \mathrm{BB}$ signaling pathways were associated with downregulation of TFF expression [29]. Detailed regulation of the TFF expression has been reported elsewhere [33]. TFFs are involved in several biological functions such as cytoprotection against tissue damage [34-36], the immune response [37, 38], and tumorigenesis [39-41]. Informative data on the biological functions of TFFs in oral compartment are very limited. Recent studies reported that TFF3 was a modifying factor in 
signaling pathways which were involved in cell survival, cell proliferation, and cell migration of oral keratinocytes [42, 43].

Aberrant expression of TFFs in tissues of human solid tumors such as breast, lung, stomach, colon, and prostate cancers has been demonstrated, and detailed expression of TFF peptides in human solid tumors of various organs has been reviewed elsewhere [44]. In addition, changes in TFF concentrations in serum of patients with prostate cancer has been reported [45]. It has been suggested that TFFs have contradictory roles in human carcinogenesis as tumor suppressor and tumor progression factors, depending on the site of expression [46]. However, the clinical significance of TFF expression in saliva and oral mucosal tissues in patients with oral squamous cell carcinoma (OSCC) has never been identified. Therefore, the aim of the present study was to quantify TFF concentrations in saliva and determine their expression patterns in oral mucosa from patients with OSCC as compared to those in healthy subjects. 


\section{Materials and Methods}

\section{Saliva specimens}

There were 46 participants in this study including 23 OSCC patients, and 23 healthy subjects. The approval of the ethical committee for the use of human subjects, Khon Kaen University (HE480239) was obtained. OSCC patients were recruited from Otorhinolaryngology Clinic, Faculty of Medicine, and Oral and Maxillofacial Surgery Clinic, Faculty of Dentistry, Khon Kaen University, Thailand. OSCC patients consisted of 7 women and 16 men with a median (range) age of 62 (26-87) years. Upon histopathologic findings, 10 cases were graded as well differentiated, 7 cases as moderate differentiation, and 6 cases as poor differentiation. Healthy individuals were recruited from Oral Diagnosis Clinic, Faculty of Dentistry, Khon Kaen University, and consisted of 10 women and 13 men with a median (range) age of 51 (42-77) years. Regarding the medical records of healthy subjects, none had systemic diseases or took medications. All participants refrained from eating or drinking one hour before saliva collection. Each participant was asked to expectorate whole saliva into a 50-mL centrifuge tube, and a final saliva volume of 3 to $5 \mathrm{~mL}$ was collected. All saliva samples were immediately placed on ice for transport. Samples were vortexed for 3 minutes, followed by centrifuging at $2300 \mathrm{~g}$ for 10 minutes. Supernatants were stored at $-80^{\circ} \mathrm{C}$ until further analysis.

\section{Oral mucosal tissue specimens}

Thirty two formalin-fixed and paraffin-embedded biopsy specimens from OSCC patients and 32 normal oral mucosa (NOM) specimens from healthy subjects were retrieved from the archives of Division of Oral Pathology, Department of Oral Diagnosis, Faculty of Dentistry, Khon Kaen University, Thailand. Clinicopathologic characteristics of OSCC and clinical information of NOM are as follows. OSCC specimens were from 18 women and 14 men with a median (range) age of 65 (39-85) years. OSCC tissue specimens were from 
buccal mucosa $(n=12)$, tongue $(n=5)$, floor of mouth $(n=5)$, gingiva $(n=4)$, retromolar area of mandible $(n=4)$, and palate $(n=2)$. Upon histopathologic findings, 11 cases were graded as well differentiated, 11 cases as of moderate differentiation, and 10 cases as poor differentiation. The biopsies of NOM were from the normal retromolar mucosa (no clinical sign of inflammation) of healthy individuals consisting of 20 women and 12 men undergoing impacted tooth removal with a median (range) age of 20 (18-30) years.

\section{Measurement of salivary TFF1, TFF2 and TFF3 peptides}

Salivary supernatants were placed on ice and treated with ultrasound for 10 seconds to disrupt the mucus. Total protein concentrations from saliva samples were determined to test whether any differences in TFF peptide concentrations could be ascribed to differences in total salivary protein concentrations, employing the BCA Protein Assay (PIERCE, VWR international). ELISA assays previously characterized [47] for measurement of TFF1, TFF2 and TFF3 in human saliva were performed. Briefly, the TFF1-ELISA is based on two polyclonal rabbit antibodies, the TFF2-ELISA on a monoclonal mouse antibody and a polyclonal rabbit antibody, and the TFF3-ELISA on two polyclonal rabbit antibodies. Recombinant human TFF1, TFF2, and TFF3 peptides were used as calibrators. Anti-human TFF1, TFF2, and TFF3 antibodies and recombinant human TFF1, TFF2 and TFF3 peptides were a kind gift from Lars Thim, Novo Nordisk, Denmark. Salivary supernatants were diluted with assay buffer and further dilutions were performed if the initial dilution was too high or too low to allow quantification of the TFF peptides in question. Recombinant human TFF1, TFF2, and TFF3 peptides as calibrators were diluted in assay buffer with concentrations ranging from $0.005-0.171 \mathrm{nmol} / \mathrm{L}$ for TFF1, 0.006-0.200 nmol/L for TFF2 and 0.003-0.183 nmol/L for TFF3. Imprecision as judged from serum pools run over a period of 1 month (mean nmol/L [\%CV]) are as follows: TFF1 (n=6): 0.013 [12], and 0.058 [10]; TFF2 (n=6): 0.010 [17] , and 0.042 [10;] TFF3 (n=6): 0.008 [7] and 0.031 [7]. All data of salivary 
TFF concentrations were normalized for total protein concentrations and analyzed as nmol TFF/g protein. According to statistical characteristics of the data, Mann- Whitney test was selected to compare differences in levels of salivary TFF1, TFF2, and TFF3 peptides between OSCC patients and healthy subjects. Significance was established at a P-value $<0.05$.

\section{Immunohistochemical study}

From each biopsy specimen, serial sections $5 \mu \mathrm{m}$ thick were cut and mounted on glass slide. Antihuman TFF1, TFF2, and TFF3 polyclonal antibodies were used as previously described [15, 48, 49]. The specificity of the antisera has been tested by lack of crossreactivity with other family trefoils (both hapten and full length recombinant protein) in immunoassay, Western blotting and immunohistochemistry, as well as the same trefoil from other species. Anti-human TFF1 antibody does not cross-react with human TFF2 or TFF3, nor with mouse or rat TFF1 C-terminal hapten [48]. The anti-human TFF2 antibody cross-reacts with mouse but not rat TFF2, but not TFF1 or TFF3 [15]. The anti-human TFF3 antibody cross-reacts with all species tested (mouse, rat, human), but not TFF1 nor TFF2 [49]. Sections were deparaffinized in xylene, hydrated through graded alcohols, and washed with phosphate buffered saline (PBS). HistoStain-Plus kit (Invitrogen, Carlsbad, CA, USA) was used for immunostaining detection. Endogenous peroxidase activity was quenched for 5 minutes. The sections were then washed in PBS. Microwave-based antigen retrieval was performed for $5 \mathrm{~min}$ with $10 \mathrm{mmol} / \mathrm{l}$ sodium citrate buffer at a $\mathrm{pH}$ of 6.0 . The optimal dilutions of primary antibodies were; 1:2000 for antihuman TFF1 antibody, 1:1000 for TFF2 antibody and 1:4000 for TFF3 antibody. Immuno-detection was performed with biotinylated anti-rabbit immunoglobulin, followed by peroxidase labelled streptavidin and aminoethyl carbazole (AEC) as substrate chromogen. All incubations were done in a humidified chamber at room temperature. Gastric and colon cancer tissues were used as positive controls. Biopsy specimens derived from OSCC and NOM were carried out by 
substituting primary antibodies with PBS and these specimens were used as negative controls for each group. Upon microscopic examination at original magnification 10X, the distributions of positively stained cells were observed in OSCC and NOM. Semi-quantitative immunostaining scores, based on degree of distribution of positively stained cells in OSCC and NOM, were graded as: $0=$ no immunostained cells; $1=$ less than $25 \%$ positively stained cells; $2=25 \%$ to $<50 \%$ positively stained cells; $3=50 \%$ to $<75 \%$ positively stained cells; 4 $\geq 75 \%$ positively stained cells. OSCC and NOM specimens were compared for differences in TFF1, TFF2, and TFF3 immunostaining scores. According to the statistical characteristics of our investigated data, Mann-Whitney U test was selected to compare the immunostaining scores between these two groups. Significance was established at a P-value $<0.05$. 
Results

Levels of salivary TFF peptides in OSCC patients and healthy subjects

The normalized concentrations (nmol/g protein) of salivary TFF1, TFF2, and TFF3 peptides are presented in Table 1. In healthy subjects and OSCC patients, TFF3 was the most abundant TFF peptide in saliva followed by TFF1 and with very little TFF2 detected. No significant differences of TFF peptides were observed between healthy subjects and OSCC patients. There were no significant correlations between levels of salivary TFFs and histopathological grading of OSCC.

Assessment of immunohistochemical staining of TFFs in biopsy specimens

Semi-quantification of TFF expression by immunohistochemistry in oral mucosal tissue specimens was presented in Table 2 and Figure 1. Expression of TFF1, TFF2, and TFF3 was detected in normal oral mucosa (NOM) of control subjects and oral mucosal tissues of OSCC patients (Figure 2). TFF1 expression in NOM was mainly detected in the cytoplasm and surface membrane of oral epithelial cells in basal and suprabasal layers, whereas TFF1 expression in OSCC was mainly detected in the cytoplasm of malignant cells (Figure 2). There were no significant differences in the TFF1 immunostaining scores between controls and OSCC patients. TFF2 expression in NOM was confined mostly to the cytoplasm of oral epithelial cells in basal and suprabasal layers (Figure 2). Most biopsy specimens in OSCC ( 22 of 32 cases) revealed no demonstrable immunostaining for TFF2 (Table 2). Significant differences in immunostaining scores of TFF2 expression between NOM and OSCC were demonstrated (Mann-Whitney $U$ test; $p<0.001$ ), with a marked reduction in TFF2 expression in OSCC compared to NOM (Table 2). TFF3 expression in NOM was mainly detected in the cytoplasm and surface membrane of oral epithelial cells in basal and suprabasal layers, whereas mild TFF3 expression in OSCC was mainly detected in 
cytoplasm of malignant cells (Figure 2). Significant differences in immunostaining scores of TFF3 expression between NOM and OSCC were demonstrated (MannWhitney $U$ test; $p=0.002$ ), with a marked reduction in TFF3 expression in OSCC compared with NOM (Table 2). There were no significant correlations between TFF expression and histopathological grading of OSCC. 


\section{Discussion}

In this study, we measured the concentrations of TFF1, TFF2, and TFF3 peptides in whole saliva and determined the expression of TFF peptides in oral mucosal tissues derived from healthy subjects and patients with OSCC. It should be noted that a marked difference in age between the two investigated groups was observed. The majority of control subjects in our study were young adults while OSCC patients were older. Thus, it is possible that a marked difference in age may affect our findings. To our knowledge, there is one recent study reporting correlations between age and levels of salivary TFF2 and TFF3 in children [50]. Secreted TFFs have been previously detected in various human body fluids [10, 17-23]. Among human serum TFF peptides, TFF1 is the most abundant, followed by TFF3 and TFF2, respectively $[17,18]$. In human saliva, our findings demonstrated that TFF3 was predominant, followed by TFF1 and TFF2. A previous study demonstrated increased levels of all three TFF peptides in plasma of patients with advanced prostate cancer [45]. In contrast, no differences in salivary TFF concentrations between healthy subjects and patients with OSCC were demonstrated. TFF peptides in saliva are mainly derived from salivary glands with some contribution from epithelial and goblet cells of the parotid duct or squamous epithelium of oral mucosa [10-12]. Saliva samples in the present study were collected from patients with OSCC lesions of the oral mucosa which did not involve the salivary glands. Only small amounts of secreted TFFs from oral epithelial cells or malignant cells from OSCC lesions likely contributed to total salivary TFFs.

Therefore, quantification of TFF levels in saliva may not be optimal in terms of diagnostic or predictive value for pathological condition of OSCC derived from oral mucosa. However, it may be of interest to quantify salivary TFF peptide secretion under pathological conditions such as salivary gland tumors, where TFF expression may be useful biomarkers of disease progression and prognosis. 
Although TFF peptides are predominantly expressed by epithelial cells of the gastrointestinal tract [6], one member of the family, TFF3 has been shown to be expressed in normal epithelial cells of parotid duct and oral squamous epithelium [12]. The present study extends these observations, showing that all three TFF peptides are expressed in the normal oral squamous epithelium. The differences in immunostaining results of TFF expression in normal oral mucosa may be due to confounding variables such as fixation, antigen retrieval techniques, types of primary antibodies, and detecting systems. In recent years, association between TFFs and carcinogenesis has been investigated. Either increased or decreased expression of TFFs has been reported in human cancers [44]. Our immunohistochemical results demonstrated a significantly decreased expression of TFF2 and TFF3 in oral squamous epithelium of OSCC patients in comparison to healthy subjects, whereas no significant differences of TFF1 expression between these two groups were observed. The present findings suggest a possible tumor suppressive role of TFF2 and TFF3 in OSCC as has been shown in the stomach $[48,51,52]$. However, such a role needs to be verified using suitable in vivo genetic models and cell lines. In addition, the apparent pro-carcinogenic role of some TFF peptides in non-gastric sites, suggests that trefoil factors may have context-specific functions in different mucosae.

There were no significant correlations between the histopathological grading of OSCC and levels of salivary TFF concentrations or levels of TFF immunostaining scores. The explanation may be due to the semi-quantitative method for the histopathological grading of OSCC. It is possible that the semi-quantitative method is not sufficiently sensitive to detect such correlations between histopathological grading of OSCC and levels of salivary TFF concentrations or levels of TFF expression in oral mucosal tissues. In addition, we could not exclude the possibility that TFF expression may not be directly affected by the pathological condition of oral carcinogenesis. One previous study 
reported that inflammation-mediated signaling transduction such as NFkB signaling pathway was associated with downregulation of TFF expression [29]. Therefore, TFF expression might be affected by the inflammatory responses in oral mucosal compartments. Further investigations are needed to validate the connection between chronic inflammatory responses in OSCC and regulation of TFF2 and TFF3 expression in oral mucosal compartments.

In conclusion, as for previous reports of altered expression of TFF peptides in patients with various cancers, the present study provided additional information of reduced TFF2 and TFF3 expression in oral mucosal tissues from patients with OSCC. These findings need to be extended in order to determine their clinical significance in OSCC. Therefore, further investigations at a molecular level are needed to clarify mechanisms regulating TFF expression in the oral compartment and the role of TFFs in the development of oral cancer. 


\section{Acknowledgements}

This research work was supported by Khon Kaen University, the Danish Medical Research Council, and the National Health and Medical Research Council (NHMRC), Australia. The authors would like to thank Professor Ebba Nexø (Department of Clinical Biochemistry, Aarhus University Hospital, Aarhus, Denmark) for research advice, Dr. Waranuch Pithipat (Department of Community Dentistry, Faculty of Dentistry Khon Kaen University, Thailand) for statistical advice, and Inger Marie Jensen (Department of Clinical Biochemistry, Aarhus University Hospital, Aarhus, Denmark) for excellent technical assistance. The authors also thank Lars Thim (Department of Protein Engineering, Novo Nordisk A/S, Måløv, Denmark) for his collaboration. 


\section{Conflicts of Interest Statement}

The authors declare that they have no conflicts of interest. 


\section{References}

1. Mori K, Fujii R, Kida N, Takahashi H, Ohkubo S, Fujino M, Ohta M, Hayashi K (1990) Complete primary structure of the human estrogen responsive gene (pS2) product. J Biochem 107:73-6.

2. Tomasetto C, Rio M, Gautier C, Wolf C, Hareuveni M, Chambon P, Lathe R (1990) $\mathrm{hSP}$, the domain-dublicated homolog of $\mathrm{pS} 2$ protein, is co-expressed with $\mathrm{pS} 2$ in the stomach but not in breast carcinoma. EMBO J 9:407-14.

3. Hauser F, Poulsom R, Chinery R, Rogers LA, Hanby AM, Wright NA, Hoffmann W (1993) hP1.B, a human P-domain peptide homologous with rat intestinal trefoil factor, is expressed also in the ulcer-associated cell lineage and the uterus. Proc Nalt Acad Sci USA 90:6961-65.

4. Thim L, May FEB (2005) Structure of mammalian trefoil factors and functional insights. Cell Mol Life Sci 62:2956-73.

5. Chinery R, Williamson J, Poulsom R (1996) The gene encoding human intestinal trefoil factor (TFF3) is located on chromosome 21q22.3 clustered with other members of the trefoil peptide family. Genomics 32:281-4.

6. Madsen J, Nielsen O, Tornøe I, Thim L, Holmskov U (2007) Tissue localization of human trefoil factors 1, 2, and 3. J Histochem Cytochem 55:505-13.

7. Jagla W, Wiede A, Dietzmann K, Rutkowski K, Hoffmann W (2000) Co-localization of TFF3 peptide and oxytocin in the human hypothalamus. FASEB J 14:1126-31.

8. Paulsen FP, Hinz M, Schaudig U, Thale AB, Hoffmann W (2002) TFF peptides in the human efferent tear ducts. Invest Ophthalmol Vis Sci 43:3359-64. 
9. Jagla W, Wiede A, Hinz M, Dietzmann K, Gülicher D, Gerlach KL, Hoffmann W (1999) Secretion of TFF-peptides by human salivary glands. Cell Tissue Res 298: $161-6$.

10. Devine DA, High AS, Owen PJ, Poulsom R, Bonass WA (2000) Trefoil factor expression in normal and diseased human salivary glands. Hum Pathol 31:509-15.

11. Kouznetsova I, Gerlach KL, Zahl C, Hoffmann W (2010) Expression analysis of human salivary glands by laser microdissection: differences between submandibular and labial glands. Cell Physiol Biochem 26:375-82.

12. Kutta H, May J, Jaehne M, Münscher A, Paulsen FP (2006) Antimicrobial defence mechanisms of the human parotid duct. J Anat 208:609-19.

13. dos Santos Silva E, Ulrich M, Döring G, Botzenhart K, Gött P (2000) Trefoil factor family domain peptides in the human respiratory tract. J Pathol 190:133-42.

14. Cook GA, Familari M, Thim L, Giraud AS (1999) The trefoil peptides TFF2 and TFF3 are expressed in rat lymphoid tissues and participate in the immune response. FEBS Lett 456:155-9.

15. Srivatsa G, Giraud AS, Ulaganathan M, Yeomans ND, Dow C, Nicoll AJ (2002) Biliary epithelial trefoil peptide expression is increased in biliary diseases. Histopathology 40:261-8.

16. Wiede A, Hinz M, Canzler E, Franke K, Quednow C, Hoffmann W (2001) Synthesis and localization of the mucin-associated TFF-peptides in the human uterus. Cell Tissue Res 303:109-15.

17. Vestergaard EM, Poulsen SS, Grønbaek H, Larsen R, Nielsen AM, Ejskjaer K, Clausen JT, Thim L, Nexø E (2002) Development and evaluation of an ELISA for human trefoil factor 3. Clin Chem 48:1689-95. 
18. Vestergaard EM, Brynskov J, Ejskjaer K, Clausen JT, Thim L, Nexø E, Poulsen SS (2004) Immunoassays of human trefoil factors 1 and 2: measured on serum from patients with inflammatory bowel disease. Scand J Clin Lab Invest 64:146-56.

19. Vestergaard EM, Nexø E, Wendt A, Guthmann F (2008) Trefoil factors in human milk. Early Hum Dev 84:631-5.

20. Kouznetsova I, Peitz U, Vieth M, Meyer F, Vestergaard EM, Malfertheiner P, Roessner A, Lippert H, Hoffmann W (2004) A gradient of TFF3 (trefoil factor family 3) peptide synthesis within the normal human gastric mucosa. Cell Tissue Res 316 : $155-65$.

21. Rasmussen TN, Thim L, Raaberg L, Harling H, Holst JJ (1990) Pancreatic spasmolytic polypeptide, a potential growth factor for the intestine: neural control of secretion. Digestion 46:226-31.

22. Rasmussen TN, Harling H, Thim L, Pierzynowski S, Weström BR, Holst JJ (1993) Regulation of secretion of pancreatic spasmolytic polypeptide from porcine pancreas. Am J Physiol 264:22-9.

23. Miyashita S, Nomoto H, Konishi H, Hayashi K (1994) Estimation of pS2 protein level in human body fluids by a sensitive two-site enzyme immunoassay. Clin Chim Acta 228:71-81.

24. Goldenring JR, Poulsom R, Ray GS, Wright N, Meise KS, Coffey RJ Jr (1996) Expression of trefoil peptides in the gastric mucosa of transgenic mice overexpressing transforming growth factor-alpha. Growth Factors 13:111-9.

25. Taupin D, Wu DC, Jeon WK, Devaney K, Wang TC, Podolsky DK (1999) The trefoil gene family are coordinately expressed immediate-early genes: EGF receptorand MAP kinase-dependent interregulation. J Clin Invest 103:31-8. 
26. Jackerott M, Lee YC, Møllgård K, Kofod H, Jensen J, Rohleder S, Neubauer N, Gaarn LW, Lykke J, Dodge R, Dalgaard LT, Søstrup B, Jensen DB, Thim L, Nexø E, Thams P, Bisgaard HC, Nielsen JH (2006). Trefoil factors are expressed in human and rat endocrine pancreas: differential regulation by growth hormone. Endocrinology 147:5752-9.

27. Tu S, Chi AL, Lim S, Cui G, Dubeykovskaya Z, Ai W, Fleming JV, Takaishi S, Wang TC (2007) Gastrin regulates the TFF2 promoter through gastrin-responsive cis-acting elements and multiple signaling pathways. Am J Physiol Gastrointest Liver Physiol 292:1726-37.

28. Nikolaidis NM, Zimmermann N, King NE, Mishra A, Pope SM, Finkelman FD, Rothenberg ME (2003) Trefoil factor-2 is an allergen-induced gene regulated by Th2 cytokines and STAT6 in the lung. Am J Respir Cell Mol Biol 29:458-64.

29. Dossinger V, Kayademir T, Blin N, Gött P (2002) Down-regulation of TFF expression in gastrointestinal cell lines by cytokines and nuclear factors. Cell Physiol Biochem 12:197-206.

30. Van De Bovenkamp JH, Korteland-Van Male AM, Büller HA, Einerhand AW, Dekker J (2005) Infection with Helicobacter pylori affects all major secretory cell populations in the human antrum. Dig Dis Sci 50:1078-86.

31. Fox JG, Rogers AB, Whary MT, Ge Z, Ohtani M, Jones EK, Wang TC (2007) Accelerated progression of gastritis to dysplasia in the pyloric antrum of TFF2 -/C57BL6 x Sv129 Helicobacter pylori-infected mice. Am J Pathol 171:1520-8.

32. Tebbutt NC, Giraud AS, Inglese M, Jenkins B, Waring P, Clay FJ, Malki S, Alderman BM, Grail D, Hollande F, Heath JK, Ernst M (2002) Reciprocal regulation of gastrointestinal homeostasis by SHP2 and STAT-mediated trefoil gene activation in gp130 mutant mice. Nat Med 8:1089-97. 
33. Baus-Loncar M, Giraud AS (2005) Multiple regulatory pathways for trefoil factor (TFF) genes. Cell Mol Life Sci 62:2921-31.

34. Playford RJ, Marchbank T, Chinery R, Evison R, Pignatelli M, Boulton RA, Thim L Hanby AM (1995) Human spasmolytic polypeptide is a cytoprotective agent that stimulates cell migration. Gastroenterology 108:108-16.

35. Tran CP, Cook GA, Yeomans ND, Thim L, Giraud AS (1999) Trefoil peptide TFF2 (spasmolytic polypeptide) potently accelerates healing and reduces inflammation in a rat model of colitis. Gut 44:636-42.

36. Carrasco R, Pera M, May FE, Westley BR, Martinez A, Morales L (2004) Trefoil factor family peptide 3 prevents the development and promotes healing of ischemiareperfusion injury in weanling rats. J Pediatr Surg 39:1693-700.

37. Mashimo H, Wu DC, Podolsky DK, Fishman MC (1996) Impaired defense of intestinal mucosa in mice lacking intestinal trefoil factor. Science 274:262-5.

38. Poulsen SS, Thulesen J, Hartmann B, Kissow HL, Nexø E, Thim L (2003) Injected TFF1 and TFF3 bind to TFF2-immunoreactive cells in the gastrointestinal tract in rats. Regul Pept 115:91-9.

39. Liu D, el-Hariry I, Karayiannakis AJ, Wilding J, Chinery R, Kmiot W, McCrea PD, Gullick WJ, Pignatelli M (1997) Phosphorylation of beta-catenin and epidermal growth factor receptor by intestinal trefoil factor. Lab Invest 77:557-63.

40. Lalani EN, Williams R, Jayaram Y, Gilbert C, Chaudhary KS, Siu LS, Koumarianou A, Playford R, Stamp GW (1999) Trefoil factor-2, human spasmolytic polypeptide, promotes branching morphogenesis in MCF-7 cells. Lab Invest 79:537-46. 
41. Rodrigues S, Van Aken E, Van Bocxlaer S, Attoub S, Nguyen QD, Bruyneel E, Westley BR, May FE, Thim L, Mareel M, Gespach C, Emami S (2003) Trefoil peptides as proangiogenic factors in vivo and in vitro: implication of cyclooxygenase2 and EGF receptor signaling. FASEB J 17:7-16.

42. Storesund T, Hayashi K, Kolltveit KM, Bryne M, Schenck K (2008) Salivary trefoil factor 3 enhances migration of oral keratinocytes. Eur J Oral Sci 116:135-40.

43. Storesund T, Schenck K, Osmundsen H, Røed A, Helgeland K, Kolltveit KM (2009) Signal transduction and gene transcription induced by TFF3 in oral keratinocytes. Eur J Oral Sci 117:511-7.

44. Perry JK, Kannan N, Grandison PM, Mitchell MD, Lobie PE (2008) Are trefoil factors oncogenic? Trends Endocrinol Metab 19:74-81.

45. Vestergaard EM, Borre M, Poulsen SS, Nexø E, Tørring N (2006) Plasma levels of trefoil factors are increased in patients with advanced prostate cancer. Clin Cancer Res 12:807-12.

46. Emami S, Rodrigues S, Rodrigue CM, Le Floch N, Rivat C, Attoub S, Bruyneel E, Gespach C (2004) Trefoil factor family (TFF) peptides and cancer progression. Peptides 25:885-98.

47. Samson MH, Chaiyarit P, Nortvig H, Vestergaad EM, Ernst E, Nexø E (2011) Trefoil factor family peptides in human saliva and in cyclical cervical mucus. Method evaluation and results on healthy individuals. Clin Chem Lab Med 49, doi: 10.1515/CCLM.2011.123.

48. Taupin D, Pedersen J, Familari M, Cook G, Yeomans N, Giraud AS (2001) Augmented intestinal trefoil factor (TFF3) and loss of pS2 (TFF1) expression precedes metaplastic differentiation of gastric epithelium. Lab Invest 81:397-408. 
49. Taupin DR, Pang KC, Green SP, Giraud AS (1995) The trefoil peptides spasmolytic polypeptide and intestinal trefoil factor are major secretory products of the rat gut. Peptides 16: 1001-5.

50. Verey F, Nexø E, Greenwood R, Berry M, Corfield AP (2011) Trefoil factor family peptides are increased in the saliva of children with mucositis. Clin Chem Lab Med DOI 10.1515/CCLM.2011.667.

51. Regalo G, Wright NA, Machado JC (2005) Trefoil factors: from ulceration to neoplasia. Cell Mol Life Sci 62:2910-15.

52. Peterson AJ, Menheniott TR, O'Connor L, Walduck AK, Fox JG, Kawakami K, Minamoto T, Ong EK, Wang TC, Judd LM, Giraud AS (2010) Helicobacter pylori Infection Methylates and Silences Trefoil Factor 2 Leading to Gastric Tumor Development in Mice and Humans. Gastroenterology 139:2005-17. 
Table 1 Levels of salivary TFF peptides in healthy subjects and patients with oral squamous cell carcinoma (OSCC)

normalised concentrations of TFF peptides (nmol/g proteins)

$\underline{\text { median }} \underline{\text { interquartile range }} \underline{\text { minimum }}$

TFF1

Healthy subjects $(n=23)$

2.61

1.46

0.98

8.39

$\operatorname{OSCC}(\mathrm{n}=23)$

2.39

3.80

0.36

38.50

(Mann-Whitney U test; $\mathbf{p}=\mathbf{0 . 3 6 2}$ )

TFF2

Healthy subjects $(\mathrm{n}=23)$

0.07

0.07

0.01

0.38

$\operatorname{OSCC}(\mathrm{n}=23)$

0.08

0.13

0.01

0.33

( Mann-Whitney $U$ test; $p=0.852$ )

TFF3

Healthy subjects $(\mathrm{n}=23)$

11.90

9.65

4.27

$\operatorname{OSCC}(n=23)$

9.76

19.26

2.77

47.10

( Mann-Whitney $U$ test; $p=0.462$ ) 
Table 2 Expression of TFF1, TFF2, and TFF3 in normal oral mucosa (NOM) from healthy subjects and oral tissues from patients with oral squamous cell carcinoma (OSCC).

\begin{tabular}{|c|c|c|c|c|c|c|}
\hline \multirow[b]{2}{*}{$\begin{array}{l}\text { Immunostaining } \\
\text { score }^{\mathrm{a}}\end{array}$} & \multicolumn{2}{|c|}{$\underline{\text { TFF1 }}$} & \multicolumn{2}{|c|}{$\underline{\text { TFF2 }}^{*}$} & \multicolumn{2}{|c|}{$\underline{\mathrm{TFF}}^{* *}$} \\
\hline & $\begin{array}{l}\text { NOM } \\
(\mathrm{n}=32)\end{array}$ & $\begin{array}{l}\text { OSCC } \\
(\mathrm{n}=32)\end{array}$ & $\begin{array}{l}\text { NOM } \\
(n=32)\end{array}$ & $\begin{array}{l}\text { OSCC } \\
(\mathrm{n}=32)\end{array}$ & $\begin{array}{l}\text { NOM } \\
(\mathrm{n}=32)\end{array}$ & $\begin{array}{l}\text { OSCC } \\
(\mathrm{n}=32)\end{array}$ \\
\hline 0 & - & 1 & 8 & 22 & - & 9 \\
\hline 1 & 14 & 20 & 19 & 9 & 12 & 14 \\
\hline 2 & 10 & 5 & 5 & 1 & 12 & 4 \\
\hline 3 & 7 & 2 & - & - & 6 & 5 \\
\hline 4 & 1 & 4 & - & - & 2 & - \\
\hline
\end{tabular}

${ }^{\mathrm{a}}$ Immunostaining score was graded as: $0=$ no immunostained cells; $1=<25 \%$ positively stained cells; $2=25 \%$ to $<50 \%$ positively stained cells; $3=50 \%$ to $<75 \%$ positively stained cells; $4 \geq 75 \%$ positively stained cells. ${ }^{*}$ The asterisk indicates a statistically significant difference of TFF2 immunostaining scores (Mann-Whitney U test; $p<0.001$ ) between in NOM and OSCC. ${ }^{* *}$ The asterisks indicate a statistically significant difference of TFF3 immunostaining scores (Mann-Whitney $U$ test; $p=0.002$ ) between in NOM and OSCC. 
Figure legends

Figure 1 Semi-quantification of TFF1 expression by immunohistochemistry in oral mucosal tissue specimens of normal oral mucosa (NOM) from healthy subjects and oral mucosal tissues from oral squamous cell carcinoma (OSCC) patients (original magnification 10X). The levels of immunostaining scores are designated as follows: $0=$ no immunostained cells; $1=$ less than $25 \%$ positively stained cells; $2=25 \%$ to $<50 \%$ positively stained cells; $3=50 \%$ to $<75 \%$ positively stained cells; $4 \geq$ 75\% positively stained cells.

Figure 2 Immunostaining of TFF1, TFF2, and TFF3 in biopsy specimens of normal oral mucosa (NOM) from healthy subjects and oral mucosal tissues from oral squamous cell carcinoma (OSCC) patients (original magnification 20X). 
Immunostaining scores

0

1

2

3

4
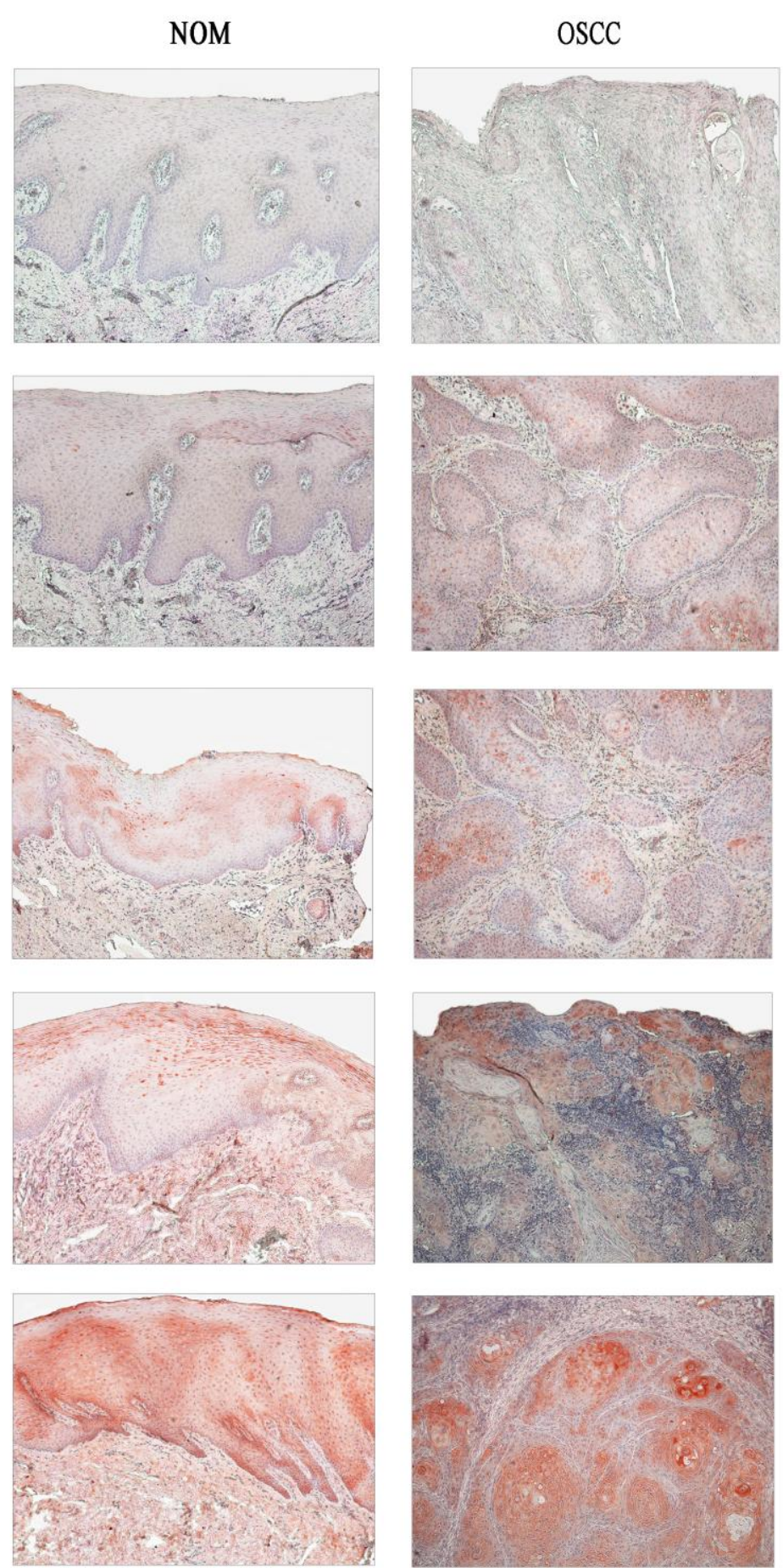
TFF immunostaining

TFF 1

TFF 2

TFF 3

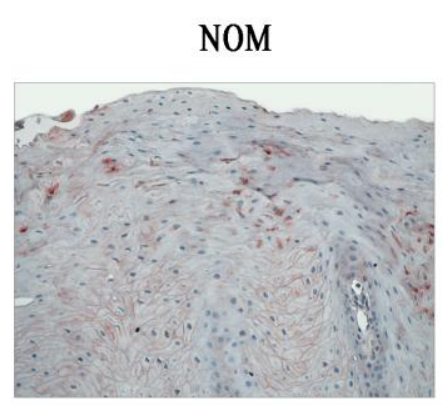

OSCC
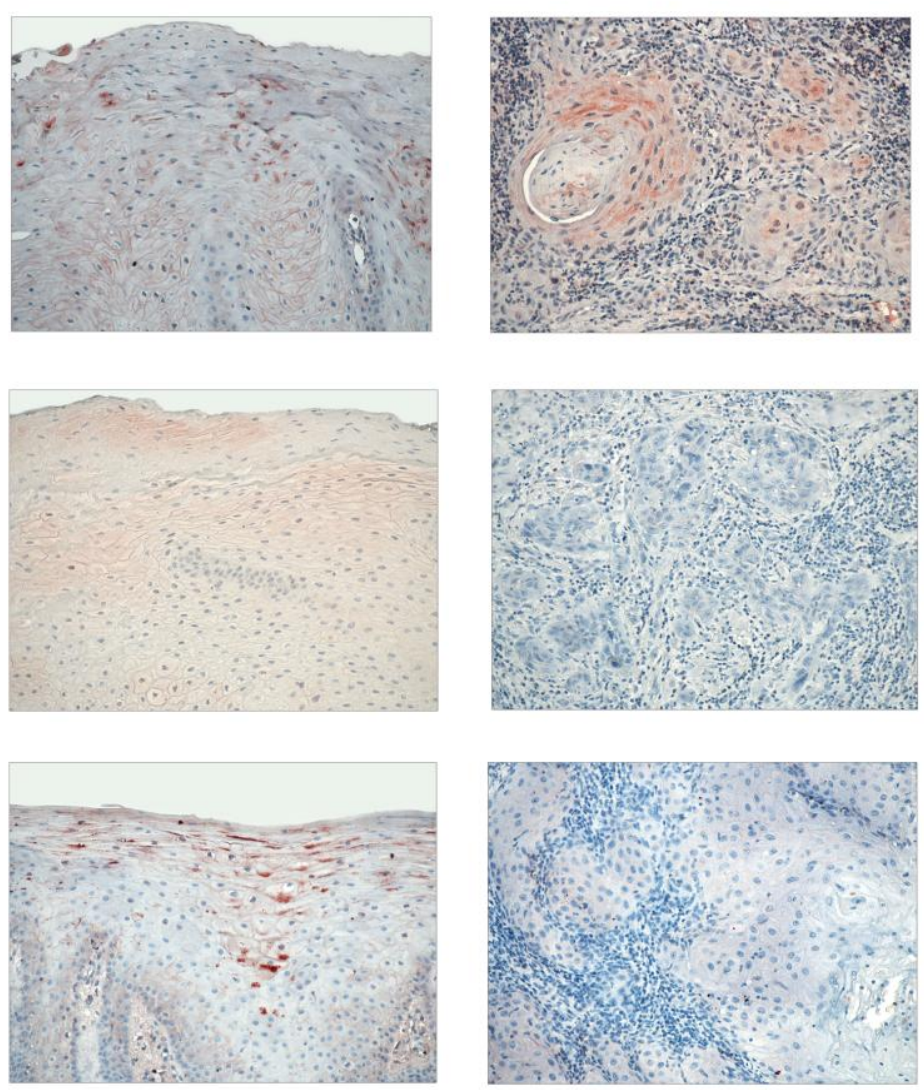